Research Article

\title{
Damage Features of Altered Rock Subjected to Drying-Wetting Cycles
}

\author{
Zhe Qin, ${ }^{1}$ Xuxin Chen ${ }^{D},{ }^{1}$ and Houli Fu ${ }^{2}$ \\ ${ }^{1}$ Shandong Province Key Laboratory of Disaster Prevention and Mitigation, \\ School of Civil Engineering and Architecture Qingdao, Shandong University of Science and Technology, \\ Shandong 266590, China \\ ${ }^{2}$ School of Civil Engineering and Architecture, Linyi University, Linyi 276000, China \\ Correspondence should be addressed to Xuxin Chen; 1757820894@qq.com
}

Received 8 September 2017; Revised 18 December 2017; Accepted 23 January 2018; Published 2 April 2018

Academic Editor: Xiang Fan

Copyright ( 2018 Zhe Qin et al. This is an open access article distributed under the Creative Commons Attribution License, which permits unrestricted use, distribution, and reproduction in any medium, provided the original work is properly cited.

\begin{abstract}
An abandoned open pit was used as a tailing pond for a concentrating mill, with the height of the water surface subject to cyclic fluctuation. The effects of drying and wetting cycles on the mechanical parameters of pit rock were tested. Interactions of the hydrochemical environment, due to the dissolution of tailings, and drying and wetting cycles caused degradation of mechanical properties in the rock. It was found that uniaxial compressive strength and elastic modulus decreased as the number of dry/wet cycles increased. The quantitative relationship between the mechanical parameters and the number of dry/wet cycles was indicated by an exponential function. In addition to uniaxial testing, cohesion and the internal friction angle were determined through triaxial testing. The shear strength index deteriorated under the drying and wetting cycles. The hydrochemical environment also negatively affected the mechanical parameters. Potential effects between drying and wetting cycles and slope displacement were analyzed by on-site monitoring. The results show that the displacement increased because of the drying and wetting cycles, which may lead to sudden failure of the slope.
\end{abstract}

\section{Introduction}

Altered rock emerged in the process of gold mineralization due to volcanic hydrothermals in earth's deep interior. An abandoned open pit conducted as a tailing pond for a concentrating mill was studied. Tailing ponds are important facilities for storing tailings and clarified water. The water level in the tailing ponds was affected by abandoned tailing emissions and clarified water extraction [1-5]. The negative influence on the stability of the open pit slope was caused by drying and wetting cycles on the altered rock. Many valuable achievements about the influence of drying and wetting cycles to various rocks have been studied by domestic and foreign researchers. Liu and Deng et al. $[6,7]$ examined the deterioration laws of sandstone under waterrock interaction, including the changes of compressive strength and rheological properties; Hua et al. [8] studied the fracture toughness of sandstone subjected to cyclic wetting and drying; the swelling behavior of volcanic rocks or mudstone and stabilized expansive soils has been studied by Vergara et al., Doostmohammadi et al., and Rao et al., respectively [9-11]; the effects of acid rain on the mechanical properties and the stability of reservoir slope slump under the condition of acid rain were examined by Liu et al. [12-14]; Zhao et al. [15] have investigated the change laws of tensile strength of sandstone with low clay mineral content; Liu et al. [16] have studied the crack growth mechanism, especially subcritical crack under water-rock interaction; and Saleh-Mbemba et al. [17] examined the water retention of tailings behavior. As for altered rock, the hydromechanical properties of altered rock have been analyzed by Wang et al. [18], and Kohno et al. and Chen et al. [19, 20] have studied the relations between point load strength index and UCS (uniaxial compressive strength) of hydrothermally altered soft rock.

However, at present, investigations on the influence of drying and wetting cycles on the mechanical properties of altered rock are deficient. The purpose of this paper is to 




FIgure 1: Open pit panorama.

TABLE 1: List of the geological characteristics of the rock engineering.

\begin{tabular}{lcc}
\hline Sample & Texture and structure & Alteration, crashing ratio \\
\hline Beresitization granoclastic & Granite blast fragmentation massive structures & Sericite-heavier, fragmentation level heavy \\
Beresitization granite & Granite blast texture block structure & Sericite-lighter, fragmentation level light \\
\hline
\end{tabular}

TABLE 2: The analysis of solution $\mathrm{pH}$ in groundwater.

\begin{tabular}{|c|c|c|c|c|c|c|c|c|c|}
\hline \multirow{2}{*}{ Sample } & \multicolumn{3}{|c|}{ Anions $(\mathrm{mg} / \mathrm{L})$} & \multicolumn{5}{|c|}{ Cations $(\mathrm{mg} / \mathrm{L})$} & \multirow{2}{*}{$\mathrm{pH}$} \\
\hline & $\mathrm{Cl}^{-}$ & $\mathrm{SO}_{4}^{2-}$ & $\mathrm{HCO}_{3}^{-}$ & $\mathrm{Na}^{+}$ & $\mathrm{Ca}^{2+}$ & $\mathrm{Mg}^{2+}$ & $\mathrm{Fe}^{3+}$ & $\mathrm{K}^{+}$ & \\
\hline Sy-1 & 13955.09 & 1910.85 & 266.11 & 7693.67 & 877.41 & 433.46 & 225.11 & 100.41 & 7.05 \\
\hline Sy-2 & 11462.34 & 1581.51 & 121.47 & 6236.54 & 926.54 & 956.65 & 372.46 & 151.24 & 7.14 \\
\hline Sy-3 & 15874.53 & 2047.81 & 158.03 & 8203.55 & 699.03 & 576.41 & 207.58 & 139.42 & 6.11 \\
\hline Sy-4 & 16469.54 & 1142.50 & 103.55 & 5779.03 & 955.68 & 395.45 & 469.57 & 121.41 & 5.84 \\
\hline Sy-5 & 19821.47 & 2237.41 & 236.47 & 9476.53 & 474.57 & 672.47 & 201.17 & 169.85 & 5.31 \\
\hline Sy-6 & 21400.51 & 2478.56 & 369.58 & 10034.12 & 399.85 & 525.17 & 187.49 & 99.47 & 4.55 \\
\hline Sy-7 & 18477.16 & 1569.44 & 294.87 & 8966.52 & 541.21 & 469.54 & 233.51 & 106.17 & 6.21 \\
\hline Sy- 8 & 20414.52 & 1966.72 & 306.22 & 9794.12 & 472.34 & 983.27 & 200.03 & 101.17 & 5.01 \\
\hline
\end{tabular}
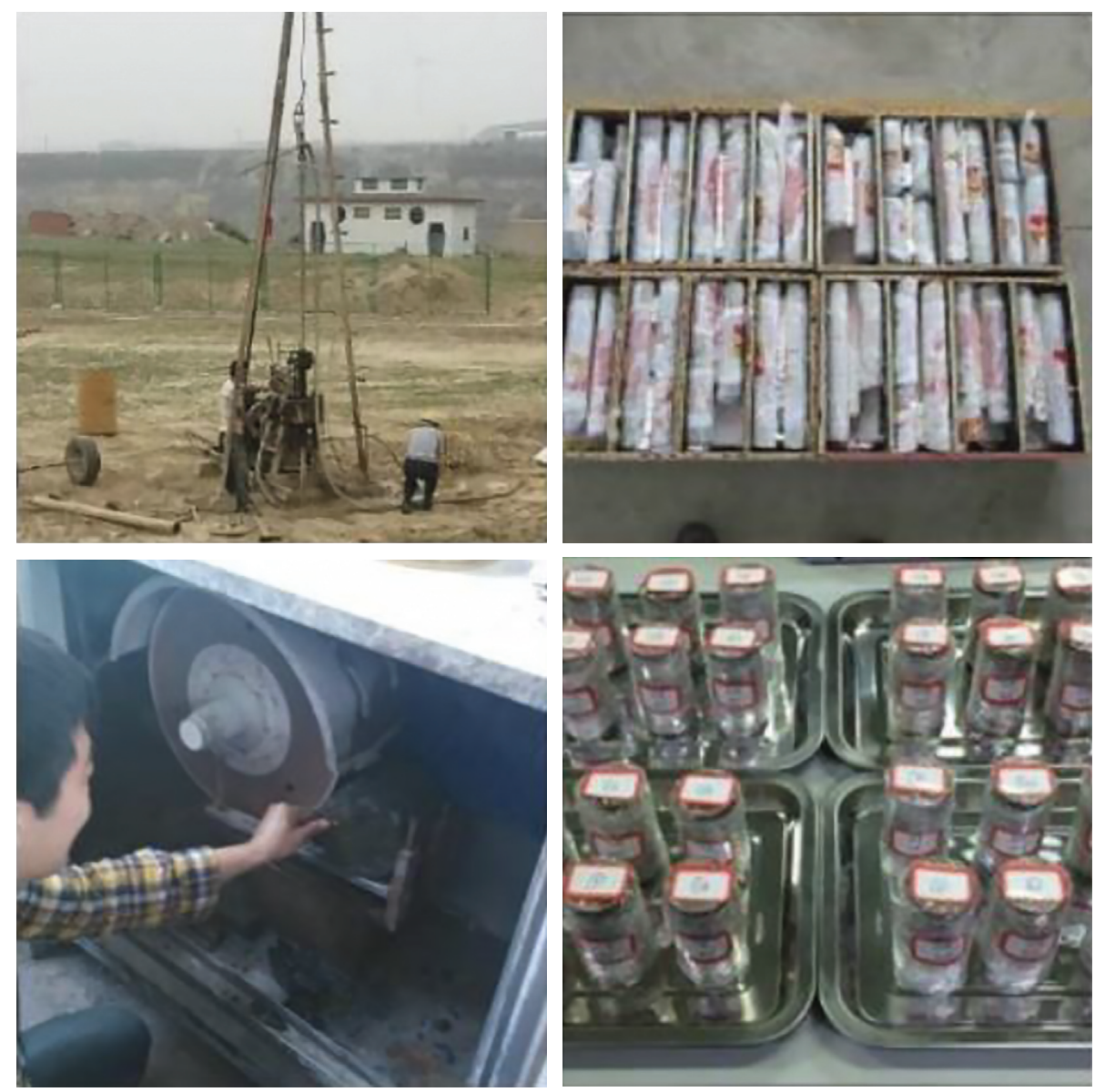

Figure 2: Preparation of rock samples. 


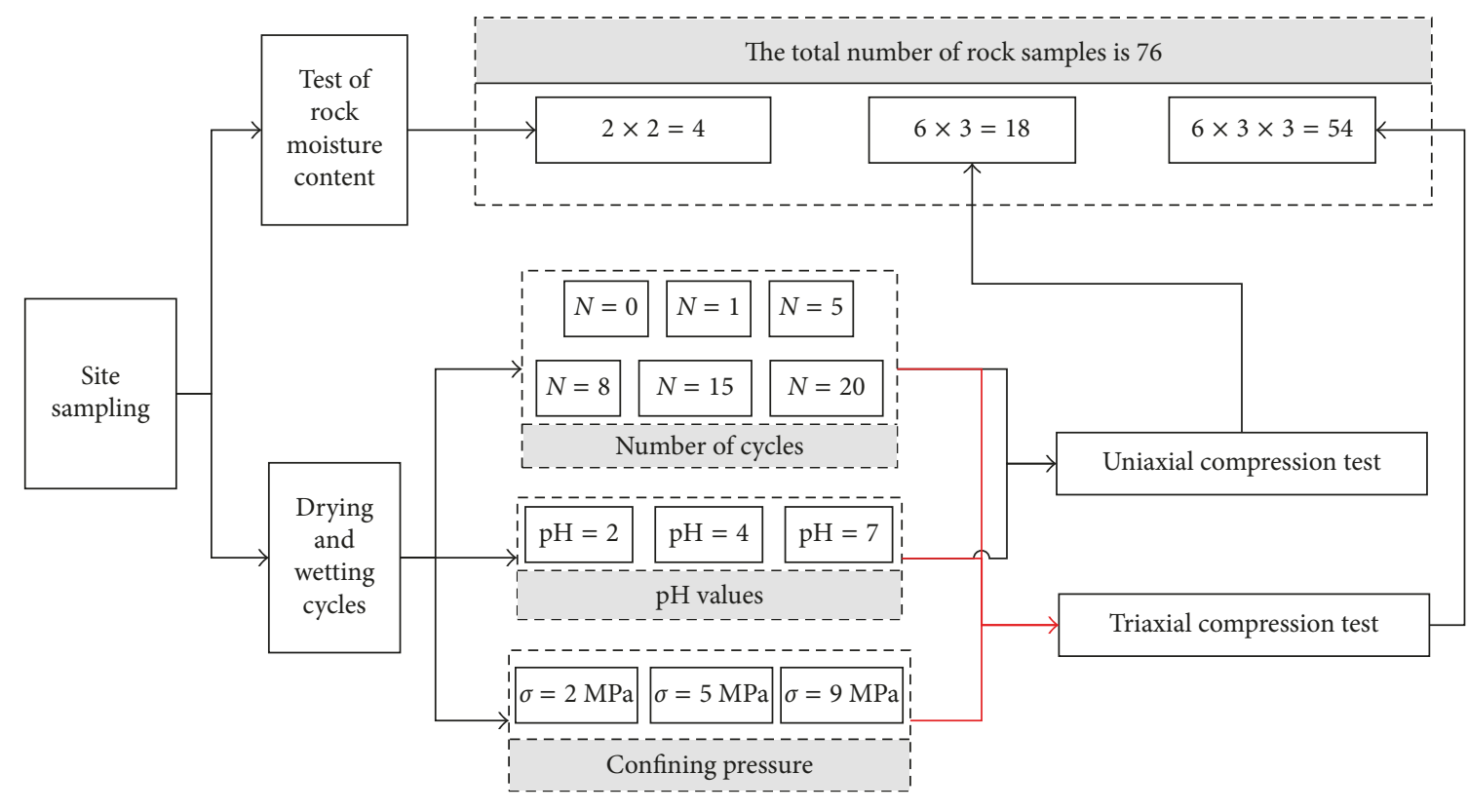

Figure 3: Test design.

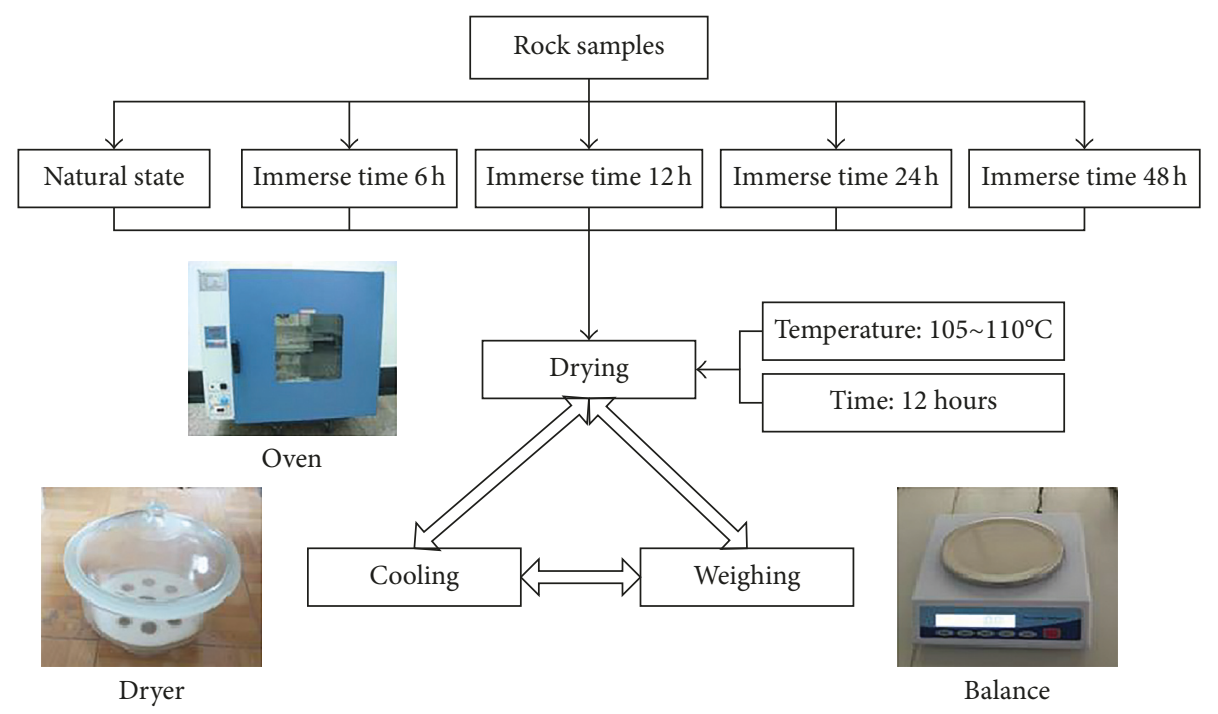

FIgURE 4: Test procedure of the moisture content.

perform laboratory tests to explore the effects on the strength and discuss the quantitative relationships between the mechanical parameters and the number of cycles. This paper also provides a theoretical basis for the analysis of the stability of open pit slopes subjected to water-rock interaction.

\section{Engineering Geology and Experimental Methods}

2.1. Engineering Geology. One of the largest opencast gold mines in China, the Cangshang gold mine, lies in Yantai City, Shandong province. A panorama of the pit is shown in Figure 1.

The gold deposits at the San Shandao-Canshang fault zone and is a typical altered rock gold deposit. Beresitization granoclastic and beresitization granite are the typical altered rocks. The engineering characteristics of these rocks are shown in Table 1.

2.2. Hydrochemical Environment. Samples of pit water and groundwater were acquired. Hydrochemical results are shown in Table 2. The main anions in the aqueous solution are $\mathrm{Cl}^{-}, \mathrm{SO}_{4}{ }^{2-}$, and $\mathrm{HCO}^{3-}$, and the main cations are $\mathrm{Na}^{+}$, $\mathrm{Ca}^{2+}, \mathrm{Mg}^{2+}, \mathrm{Fe}^{3+}$, and $\mathrm{K}^{+}$. The aqueous solution was significantly acidic.

\subsection{Experimental Methods}

2.3.1. Experiment Preparation. Specimens of altered rock were obtained from the slope of the Cangshang pit. Standard 


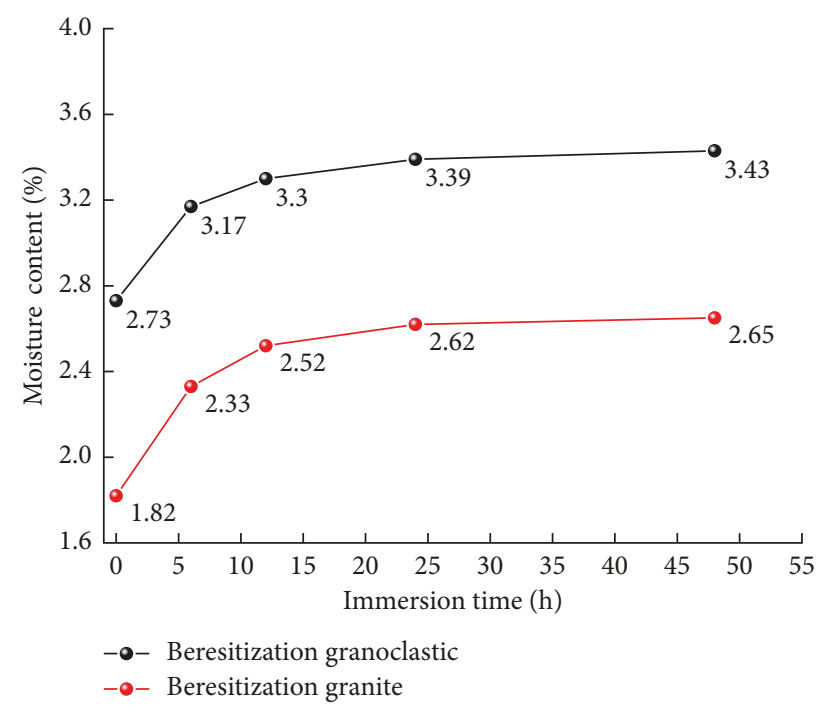

Figure 5: Test curve of the moisture content.

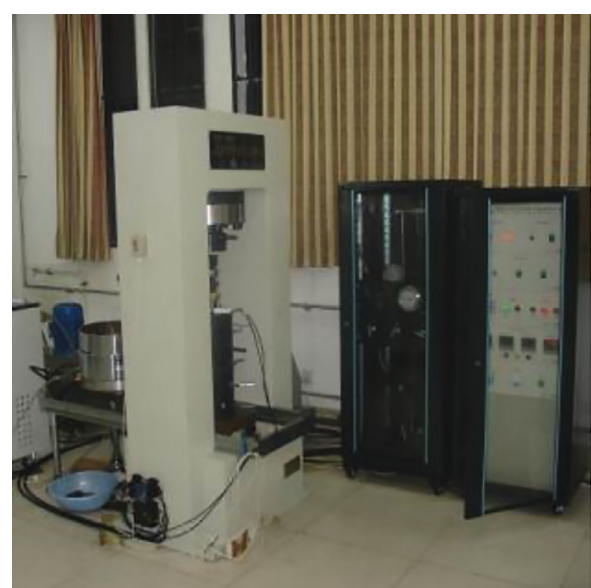

(a)

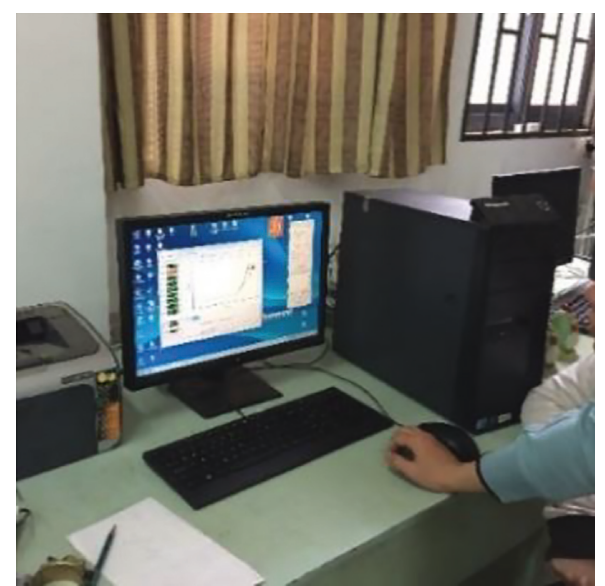

(b)

Figure 6: Sample and test equipment of compression.

cylindrical samples ( $50 \mathrm{~mm}$ diameter $\times 100 \mathrm{~mm}$ length) were obtained through core drilling and sawing, and ends of the samples were ground to flatness of less than $0.05 \mathrm{~mm}$. Figure 2 shows the preparation of rock samples.

To simulate the acidic conditions of the tailing bank slope, hydrogen chloride solutions with other chemical reagents were prepared with the $\mathrm{pH}$ values of 2,4 , and 7 in the laboratory. The rock samples were subjected to $1,5,8,15$, and 20 drying and wetting cycles in different hydrochemical environments. The test design is shown in Figure 3.

The hydrochloric acid solutions were used to simulate acidic environments with the $\mathrm{pH}$ values of 2 and 4 . Distilled water was used to simulate the neutral environment. To avoid the volatilization of the liquid in the test, the $\mathrm{pH}$ of the solution was measured once per hour to ensure that the solution $\mathrm{pH}$ is stable.

2.3.2. Test of Rock Moisture Content. The test procedure for the rock moisture content is shown in Figure 4. The immersion time in the experiment was determined by measuring the moisture content for different immersion time $(0,6,12,24$, and $48 \mathrm{~h})$.

Drying and cooling were repeated until the specimen had constant weight; that is, the relative difference between two weights over $12 \mathrm{~h}$ was less than $0.1 \%$. The moisture content of different immersion conditions was computed according to the following equation:

$$
\omega=\left(\frac{M_{1}}{M_{2}}-1\right) \times 100 \%,
$$

where $\omega$ is the moisture content, $M_{1}$ is the sample mass before drying, and $M_{2}$ is the sample mass after drying.

The results of the moisture content test are shown in Figure 5. The moisture content of rock increased by $0.03 \%-0.04 \%$ after immersion for $48 \mathrm{~h}$ compared with that of immersion for $24 \mathrm{~h}$, and the moisture content tended to be saturated after immersion for 24 hours. A drying and 

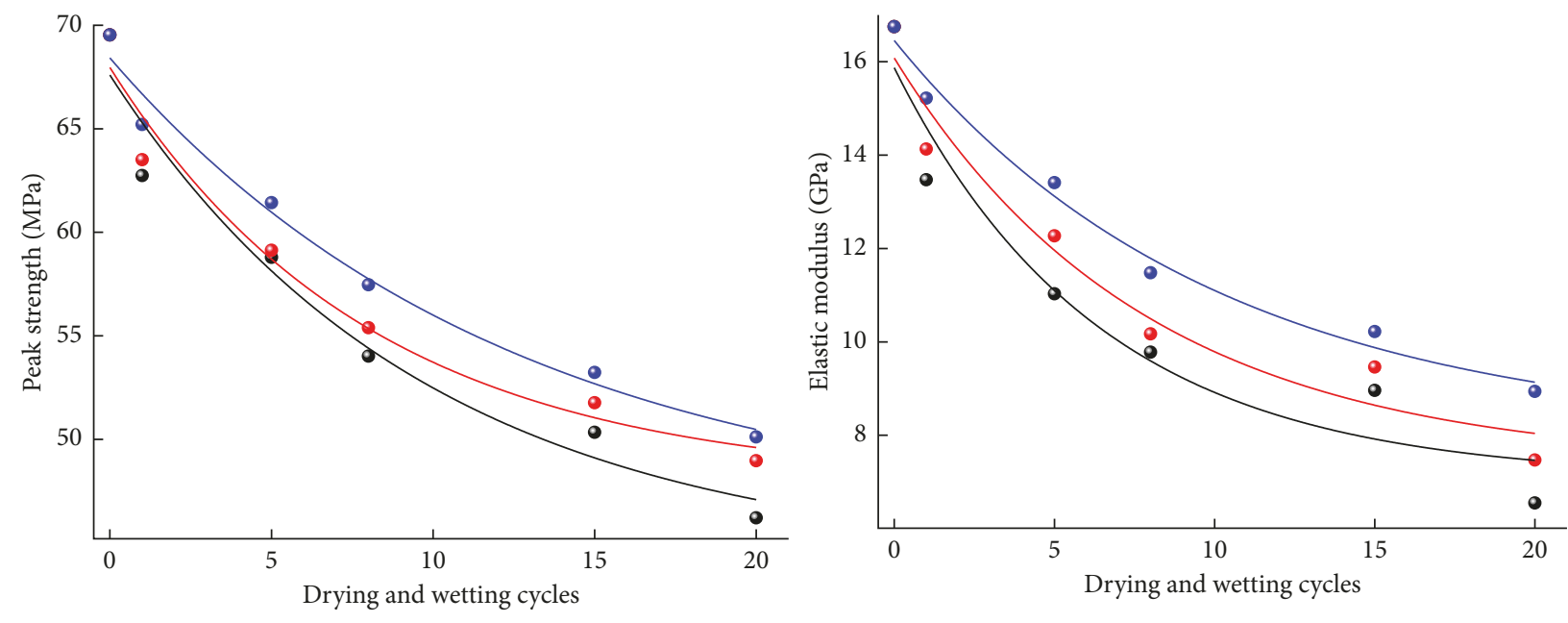
- $\mathrm{pH}=2$
- $\mathrm{pH}=4$
- $\mathrm{pH}=7$

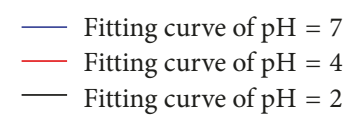

- $\mathrm{pH}=2$

- $\mathrm{pH}=4$

- $\mathrm{pH}=7$

- Fitting curve of $\mathrm{pH}=7$

- Fitting curve of $\mathrm{pH}=4$

- Fitting curve of $\mathrm{pH}=2$

(a)
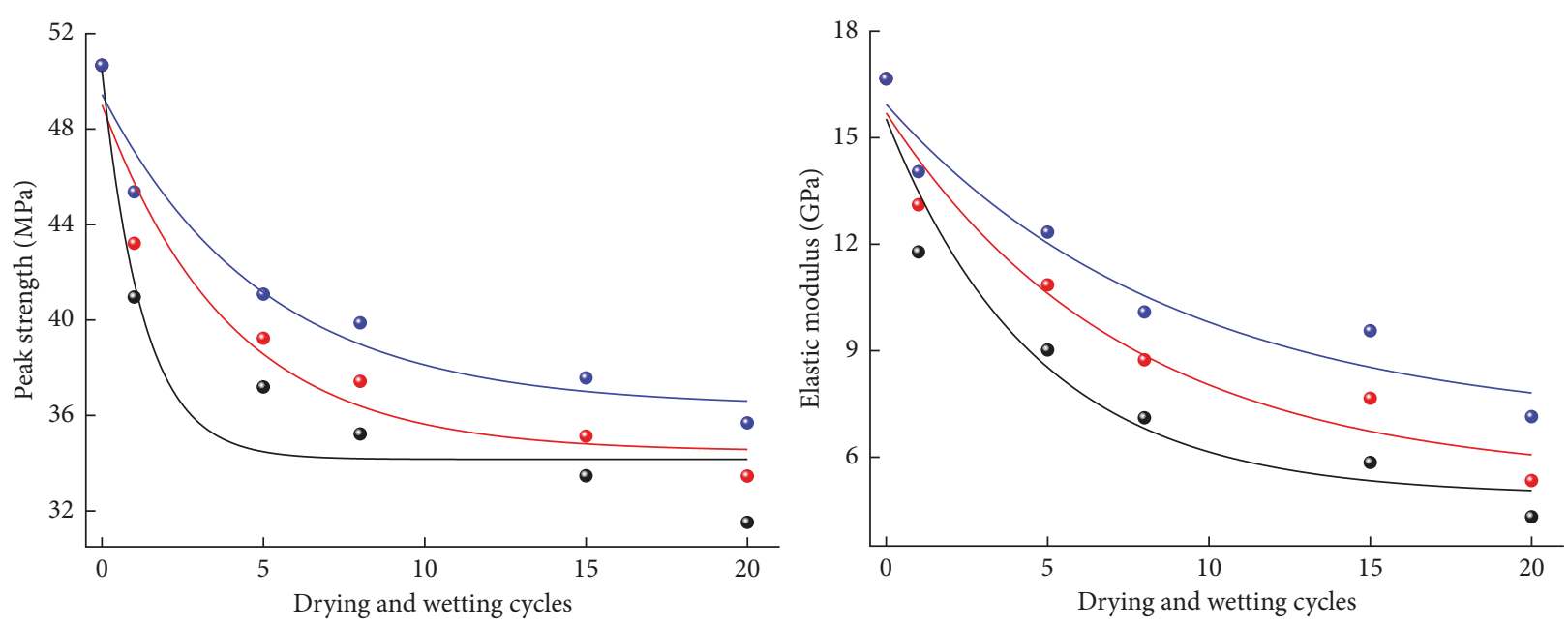
- $\mathrm{pH}=2$
- $\mathrm{pH}=4$
- $\mathrm{pH}=7$

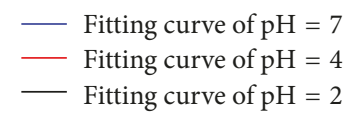

- $\mathrm{pH}=2$

- $\mathrm{pH}=4$

- $\mathrm{pH}=7$

Fitting curve of $\mathrm{pH}=7$
Fitting curve of $\mathrm{pH}=4$
Fitting curve of $\mathrm{pH}=2$

(b)

FIgURE 7: The fitting relationship between mechanics parameters and cycles. (a) Beresitization granoclastic. (b) Beresitization granite.

TABLE 3: Uniaxial compression test of the altered rock.

\begin{tabular}{|c|c|c|c|c|c|c|c|}
\hline \multirow{2}{*}{ Rock } & \multirow{2}{*}{ Cycles } & \multicolumn{3}{|c|}{ Peak strength $(\mathrm{MPa})$} & \multicolumn{3}{|c|}{ Elastic modulus (GPa) } \\
\hline & & 2 & 4 & 7 & 2 & 4 & 7 \\
\hline \multirow{6}{*}{ Beresitization granoclastic } & 0 & 69.53 & 69.53 & 69.53 & 16.75 & 16.75 & 16.75 \\
\hline & 1 & 62.74 & 63.51 & 65.21 & 13.47 & 14.13 & 15.22 \\
\hline & 5 & 58.79 & 59.13 & 61.43 & 11.03 & 12.27 & 13.41 \\
\hline & 8 & 54.02 & 55.39 & 57.47 & 9.78 & 10.17 & 11.48 \\
\hline & 15 & 50.34 & 51.77 & 53.23 & 8.96 & 9.46 & 10.22 \\
\hline & 20 & 46.21 & 48.97 & 50.12 & 6.55 & 7.47 & 8.94 \\
\hline \multirow{6}{*}{ Beresitization granite } & 0 & 50.67 & 50.67 & 50.67 & 16.66 & 16.66 & 16.66 \\
\hline & 1 & 40.96 & 43.21 & 45.37 & 11.78 & 13.11 & 14.04 \\
\hline & 5 & 37.19 & 39.23 & 41.08 & 9.02 & 10.85 & 12.34 \\
\hline & 8 & 35.22 & 37.43 & 39.88 & 7.11 & 8.74 & 10.09 \\
\hline & 15 & 33.47 & 35.13 & 37.57 & 5.85 & 7.66 & 9.56 \\
\hline & 20 & 31.52 & 33.46 & 35.69 & 4.32 & 5.34 & 7.14 \\
\hline
\end{tabular}


TABLE 4: The fitting expression between mechanics parameters and cycles.

\begin{tabular}{|c|c|c|c|c|c|}
\hline Rock & $\mathrm{pH}$ & Peak strength $(\mathrm{MPa})$ & $R^{2}$ & Elastic modulus $(\mathrm{GPa})$ & $R^{2}$ \\
\hline \multirow{3}{*}{ Beresitization granoclastic } & 2 & $y=23.51 \exp (-n / 9.71)+44.09$ & 0.936 & $y=8.79 \exp (-n / 6.39)+7.08$ & 0.900 \\
\hline & 4 & $y=20.03 \exp (-n / 8.06)+47.93$ & 0.954 & $y=8.71 \exp (-n / 7.82)+7.37$ & 0.928 \\
\hline & 7 & $y=22.37 \exp (-n / 12.35)+46.05$ & 0.975 & $y=8.45 \exp (-n / 9.98)+8.00$ & 0.978 \\
\hline \multirow{3}{*}{ Beresitization granite } & 2 & $y=16.28 \exp (-n / 1.27)+34.17$ & 0.887 & $y=10.61 \exp (-n / 4.64)+4.92$ & 0.913 \\
\hline & 4 & $y=14.53 \exp (-n / 3.94)+34.49$ & 0.898 & $y=10.31 \exp (-n / 7.37)+5.38$ & 0.918 \\
\hline & 7 & $y=13.08 \exp (-n / 4.97)+36.37$ & 0.930 & $y=9.09 \exp (-n / 8.89)+6.85$ & 0.909 \\
\hline
\end{tabular}

TABle 5: Triaxial compression data.

\begin{tabular}{|c|c|c|c|c|c|c|c|}
\hline \multirow{3}{*}{ Rock } & \multirow{3}{*}{ Cycles } & \multicolumn{3}{|c|}{ Cohesion (MPa) } & \multicolumn{3}{|c|}{ Internal friction angle $\left({ }^{\circ}\right)$} \\
\hline & & \multicolumn{3}{|c|}{ Different $\mathrm{pH}$ values } & \multicolumn{3}{|c|}{ Different $\mathrm{pH}$ values } \\
\hline & & 2 & 4 & 7 & 2 & 4 & 7 \\
\hline \multirow{6}{*}{ Beresitization granoclastic } & 0 & 13.35 & 13.35 & 13.35 & 27.26 & 27.26 & 27.26 \\
\hline & 1 & 10.17 & 11.56 & 12.39 & 23.56 & 25.12 & 26.66 \\
\hline & 5 & 7.02 & 7.94 & 9.54 & 22.53 & 23.17 & 24.22 \\
\hline & 8 & 5.56 & 6.55 & 8.62 & 21.46 & 22.15 & 23.79 \\
\hline & 15 & 4.64 & 5.47 & 6.44 & 19.45 & 20.27 & 21.33 \\
\hline & 20 & 3.01 & 3.66 & 4.06 & 17.69 & 18.27 & 19.51 \\
\hline \multirow{6}{*}{ Beresitization granite } & 0 & 9.19 & 9.19 & 9.19 & 50.01 & 50.01 & 50.01 \\
\hline & 1 & 6.94 & 8.03 & 8.51 & 45.02 & 46.34 & 47.89 \\
\hline & 5 & 5.56 & 6.96 & 7.01 & 41.78 & 43.96 & 45.02 \\
\hline & 8 & 3.12 & 5.02 & 5.94 & 40.68 & 42.04 & 43.19 \\
\hline & 15 & 2.10 & 2.91 & 3.59 & 38.57 & 40.11 & 42.01 \\
\hline & 20 & 1.67 & 2.00 & 2.81 & 37.94 & 39.57 & 41.34 \\
\hline
\end{tabular}

wetting cycle consisted of freely submerging the specimen in water until it was saturated, then placing it into a $105^{\circ} \mathrm{C}$ oven for 12 hours, and then cooling it to room temperature.

\section{Results and Analysis}

3.1. Uniaxial Compression Test. An RLJW-2000 computercontrolled rock servo triaxial and shearing compression testing machine was used to test the cylindrical samples (Figures 6 and 7).

Strength and elastic modulus of altered rock were obtained through uniaxial compression tests, and the test results are shown in Table 3.

As the number of drying and wetting cycles increased, the values of peak strength and elastic modulus gradually decreased. After one dry/wet cycle at $\mathrm{pH}=2$, the values of peak strength and elastic modulus of beresitization granoclastic and beresitization granite decreased by $10.15 \%$, $19.58 \%$ and $19.16 \%, 21.31 \%$, respectively. After 20 cycles, the peak strength and elastic modulus decreased to $66.46 \%$, $39.11 \%$ and $62.21 \%, 25.93 \%$, respectively, of natural rock. Both beresitization granoclastic and beresitization granite presented the most serious damage at $\mathrm{pH}=2$ and 20 drying and wetting cycles.

The values of peak strength and elastic modulus were fitted by a curve. The fitting results are shown in Table 4.

$$
y=a \exp \left(\frac{-n}{b}\right)+c
$$

where $a, b$, and $c$ are fitting parameters and $n$ is the number of drying and wetting cycles.

3.2. Triaxial Compression Test. Triaxial compression tests with different confining pressures $(2 \mathrm{MPa}, 5 \mathrm{MPa}$, and $9 \mathrm{MPa}$ ) were performed under various water chemistry conditions $(\mathrm{pH}=2,4$, and 7$)$ and several drying and wetting cycles $(0,1,5,8,15$, and 20). First, the specimen was compressed axially to $0.2 \mathrm{kN}$ to bring it into close contact with the bearing plate. Then, the axial pressure value, the deformation value, and the confining pressure value of the rock specimen were set to zero. The specimen was loaded at $1.5 \mathrm{MPa} / \mathrm{s}$ lateral pressure. The confining pressure varied by less than $\pm 2 \%$ of the initial value. Then, axial loading was applied with a rate of $0.2 \mathrm{~mm} / \mathrm{min}$ until the rock failed.

According to the triaxial compression test results and the Mohr-Coulomb criterion [17], the Mohr circle and its envelope at different stress states were plotted to obtain the cohesion and internal friction angle [18]. The test results are shown in Table 5.

The values of cohesion and internal friction angle decreased as the number of drying and wetting cycles increased. Relationship between cohesion, internal friction angle, and number of dry/wet cycles was fitted by the exponential curve, as shown in Figure 8. Table 6 shows equations of the fitting curves in Figure 8 and their $R^{2}$ values. Under the same $\mathrm{pH}$ conditions, the cohesion and internal friction angle of both rocks decreased as the number of 

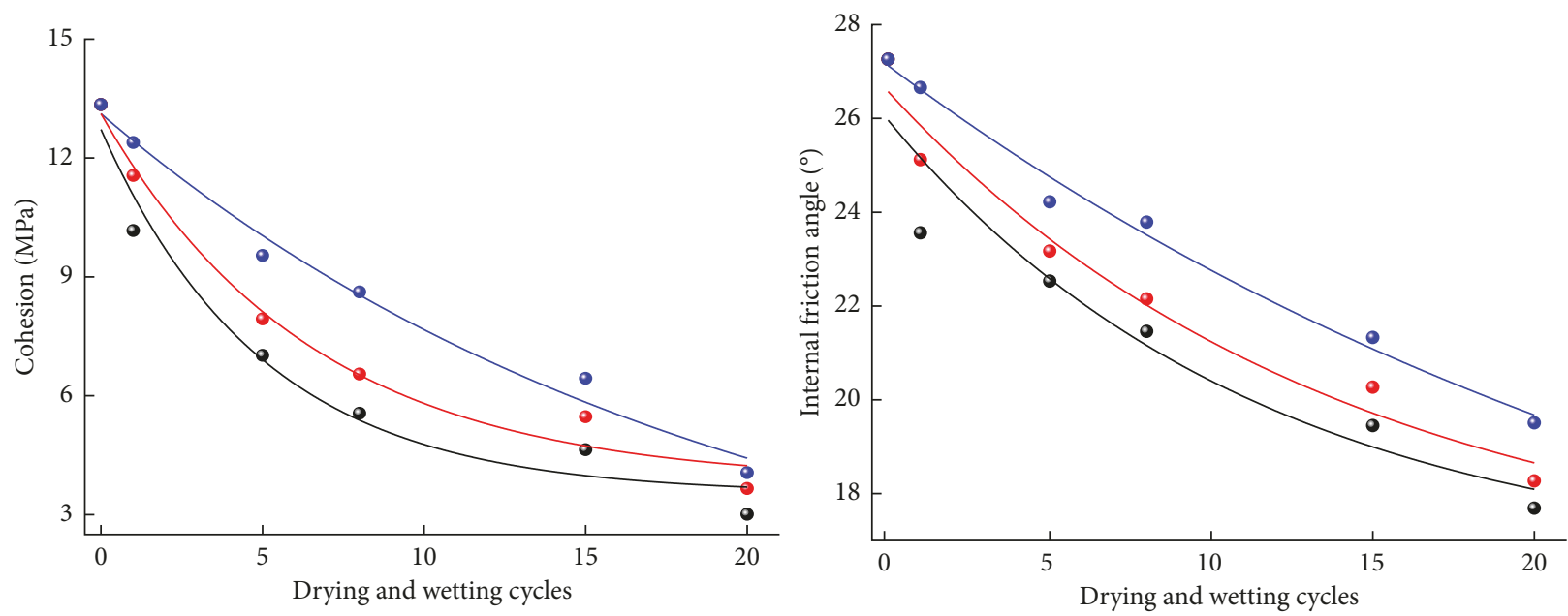
- $\mathrm{pH}=2$
- $\mathrm{pH}=4$
Fitting curve of $\mathrm{pH}=7$
Fitting curve of $\mathrm{pH}=4$
Fitting curve of $\mathrm{pH}=2$

- $\mathrm{pH}=2$
- $\mathrm{pH}=4$

- $\mathrm{pH}=7$

- Fitting curve of $\mathrm{pH}=7$

- Fitting curve of $\mathrm{pH}=4$

- Fitting curve of $\mathrm{pH}=2$

(a)
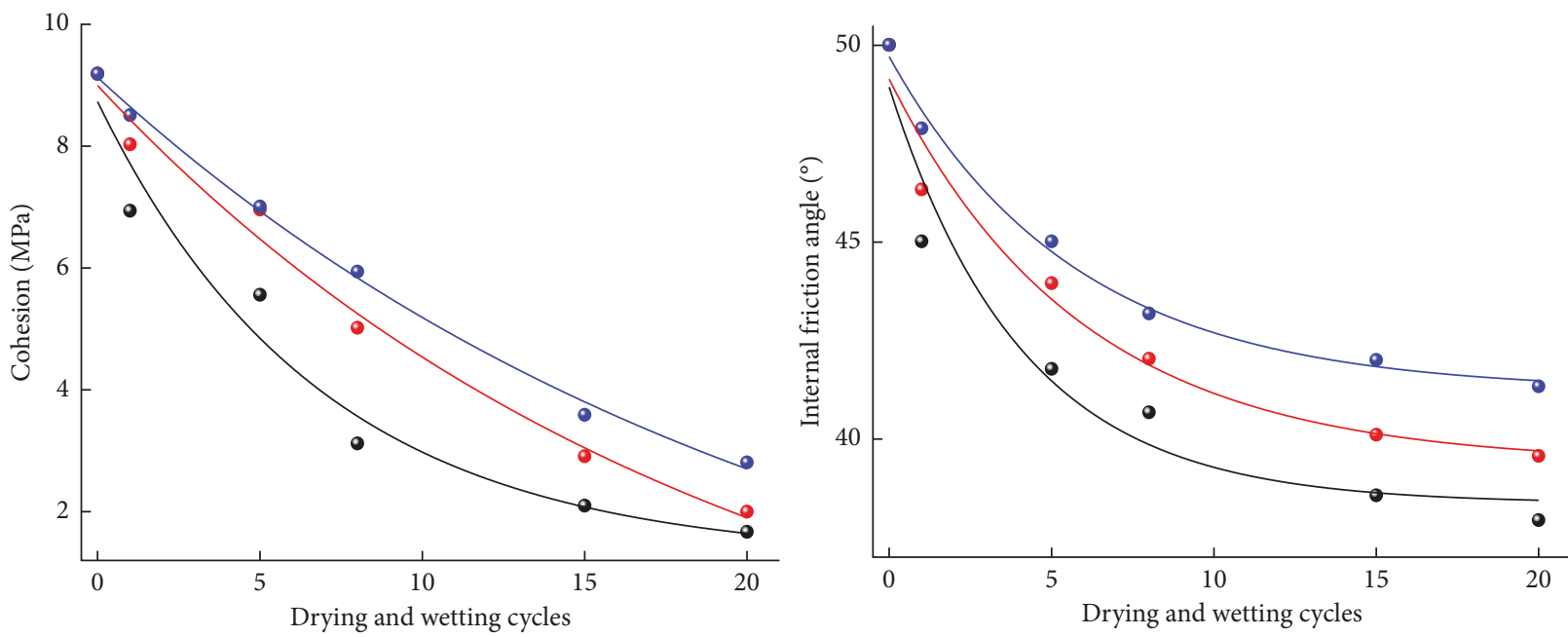
- $\mathrm{pH}=2$
- $\mathrm{pH}=4$
Fitting curve of $\mathrm{pH}=7$
Fitting curve of $\mathrm{pH}=4$
Fitting curve of $\mathrm{pH}=2$

- $\mathrm{pH}=2$

- $\mathrm{pH}=4$

- $\mathrm{pH}=7$

— Fitting curve of $\mathrm{pH}=7$

- Fitting curve of $\mathrm{pH}=4$

Fitting curve of $\mathrm{pH}=2$

(b)

Figure 8: The fitting relationship between shear strength parameters and cycles. (a) Beresitization granoclastic. (b) Beresitization granite.

TABLE 6: The fitting expression between mechanics parameters and cycles.

\begin{tabular}{|c|c|c|c|c|c|}
\hline Rock & $\mathrm{pH}$ & Peak strength $(\mathrm{MPa})$ & $R^{2}$ & Elastic modulus $(\mathrm{GPa})$ & $R^{2}$ \\
\hline \multirow{3}{*}{ Beresitization granoclastic } & 2 & $y=9.20 \exp (-n / 5.00)+3.53$ & 0.952 & $y=9.52 \exp (-n / 11.39)+16.45$ & 0.859 \\
\hline & 4 & $y=9.31 \exp (-n / 6.50)+3.80$ & 0.954 & $y=10.34 \exp (-n / 13.79)+16.23$ & 0.951 \\
\hline & 7 & $y=13.45 \exp (-n / 19.25)-0.34$ & 0.975 & $y=14.89 \exp (-n / 28.84)+12.23$ & 0.983 \\
\hline \multirow{3}{*}{ Beresitization granite } & 2 & $y=7.49 \exp (-n / 6.84)+1.24$ & 0.996 & $y=10.57 \exp (-n / 4.09)+38.37$ & 0.922 \\
\hline & 4 & $y=10.91 \exp (-n / 19.06)-1.92$ & 0.979 & $y=9.77 \exp (-n / 5.89)+39.3$ & 0.946 \\
\hline & 7 & $y=10.68 \exp (-n / 21.74)-1.56$ & 0.930 & $y=8.48 \exp (-n / 5.71)+41.23$ & 0.989 \\
\hline
\end{tabular}

wet-dry cycles increased. Specifically, cohesion of beresitization granoclastic decreased from $13.35 \mathrm{MPa}$ to $3.01 \mathrm{MPa}$, a reduction of about $77.45 \%$. The internal friction angle decreased from $27.26^{\circ}$ to $17.69^{\circ}$, and the reduction was about $37.11 \%$. The cohesion of beresitization granite decreased from $9.19 \mathrm{MPa}$ to $1.67 \mathrm{MPa}$, with a reduction of about 


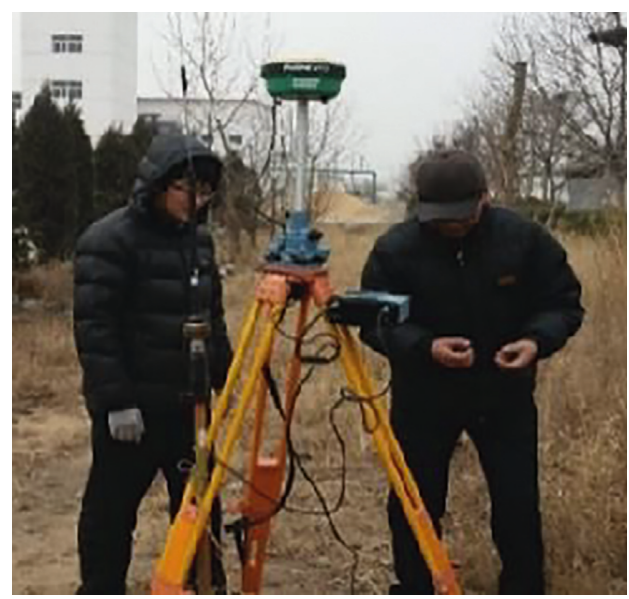

(a)

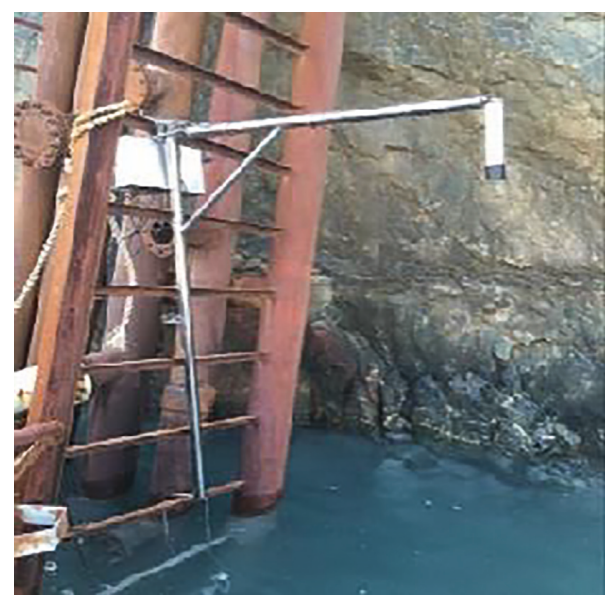

(b)

FIGURE 9: Monitoring equipment and monitoring points. (a) GPS monitoring. (b) Water level monitoring equipment.

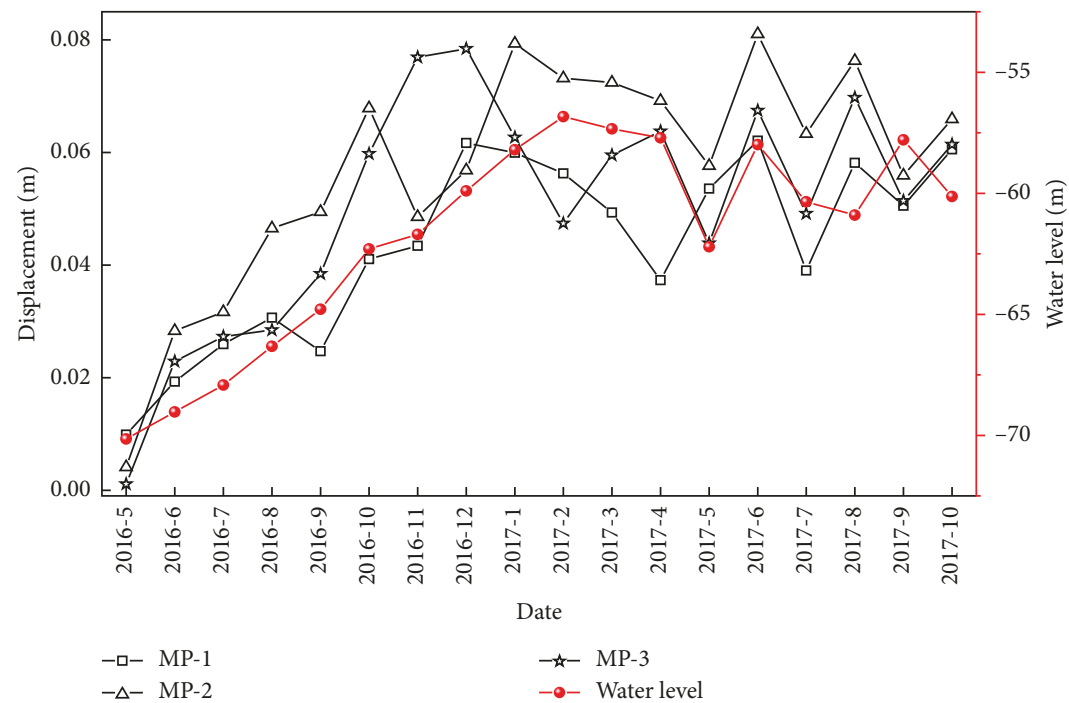

(a)

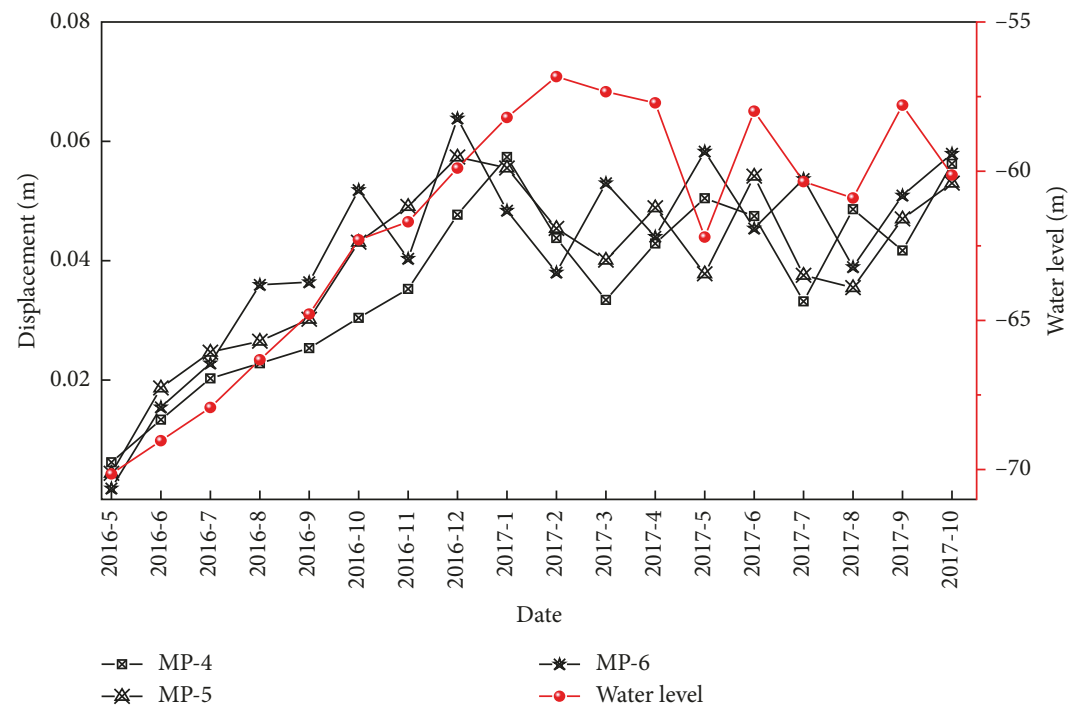

(b)

Figure 10: Relationship between slope displacement and water level change. (a) Monitoring points 1, 2, and 3. (b) Monitoring points 4, 5, and 6. 
$81.83 \%$. The internal friction angle decreased from $50.01^{\circ}$ to $37.94^{\circ}$, a reduction of about $24.14 \%$. Therefore, the drying and wetting cycles caused a greater degree of damage to beresitization granite. Overall, drying and wetting cycles significantly affect the cohesion and internal friction angle.

\section{Slope Displacement On-Site Monitoring}

The effect of drying and wetting cycles on the rock cohesion and internal friction angle is significant, which may lead to slope failure in the pit. The change of water level in the tailing reservoir and surface displacement were monitored to analyze the influence of water level on the slope displacement. GPS displacement detection and a YCY-3-type water level monitor were used, as shown in Figure 9.

Six monitoring points were set including MP-1, MP-2, MP-3, MP-4, MP-5, and MP-6. The displacement changes at the monitoring points are similar, as shown in Figure 10. From May 2016 to December 2016, the slope displacement gradually grew with the continuous increase of tailing water level. The maximum displacement value was $79.35 \mathrm{~mm}$. From December 2016 to October 2017, the water level in the tailing pond fluctuated, resulting in long-term wetting and drying cycles of the slope rock. The trend of slope displacement fluctuation was basically consistent with that of water level, indicating that the wetting and drying cycles increased the slope slip to a certain extent.

\section{Conclusion}

In this paper, laboratory tests and on-site monitoring were used to analyze the impact of drying and wetting cycles on rock strength and slope stability. The following conclusions are drawn:

The water level of the tailing reservoir will have a weakening effect on the rock strength of the slope. In the laboratory, the effect of water level that rises and falls to rock was simulated by the test of drying and wetting cycles. The rock compressive strength, elastic modulus, cohesion, and internal friction angle were analyzed. As the number of wetting and drying cycles and the acidity increased, the rock strength decreased. An exponential function predicted the decrease of strength as a function of $n$. The results show that the change of water level weakens rock strength.

Based on the laboratory analysis of rock subjected to wetting and drying cycles and site monitoring results of slope displacement, the slope displacement increased suddenly with the rise and fall of the tailings pond, indicating that the wetting and drying cycles negatively affect slope stability.

\section{Conflicts of Interest}

The authors declare that there are no conflicts of interest regarding the publication of this paper.

\section{Acknowledgments}

This paper is supported by Project no. ZR2017BEE014 of the Shandong Provincial Natural Science Foundation and Scientific
Research Foundation of Shandong University of Science and Technology for Recruited Talents (2017RCJJ050). The financial aids are gratefully acknowledged.

\section{References}

[1] H. Zhao, J. Sun, H. Ling, K. Shen, and S. Hu, "Characteristics and geological significance of ore-forming fluids in the Jiaodong gold deposits," Geology and Exploration, vol. 41, no. 5, pp. 27-33, 2005.

[2] D. Liu, G. Lu, P. Zhang et al., "A study of 3D ore-controlling of the tectonic altered rocks of the Sanshandao fault in Jiaodong Peninsular and the discovery of an offshore super-large gold deposit in China," Earth Science Frontiers, vol. 22, no. 4, pp. 162-172, 2015.

[3] X. Chen, H. Fu, Z. Qin, and H. Zhu, "Stability analysis for slope with alteration zone subjected to dry-wet cycles," Mining and Metallurgical Engineering, vol. 37, no. 4, pp. 32-35, 2017.

[4] X. Chen, H. Fu, and Z. Qin, "Energy analysis of the evolution of open-pit slope rock damage under the effect of wetting and drying circulation," Science Technology and Engineering, vol. 16, no. 20, pp. 247-252, 2016.

[5] Z. Qin, H. Fu, W. Cheng, and Y. Yu, "Creep curve of rock at open-pit slope under water-rock interaction," Journal of Yangtze River Scientific Research Institute, vol. 34, no. 3, pp. 85-89, 2017.

[6] Y. Liu, Damage Evolution and Rheological Behavior of Deep Rock Mass under Water-Rock Interaction, Central South University, Changsha, China, 2012.

[7] H. Deng, Z. Xiao, J. Li, Y. Hu, and M. Zhou, "Deteriorating change rule test research of damage sandstone strength under water-rock interaction," Chinese Journal of Rock Mechanics and Engineering, vol. 34, no. 1, pp. 2690-2698, 2015.

[8] W. Hua, S. Dong, Y. Li, and Q. Wang, "Effect of cyclic wetting and drying on the pure mode II fracture toughness of sandstone," Engineering Fracture Mechanics, vol. 153, pp. 143-150, 2016.

[9] M. R. Vergara and T. Triantafyllidis, "Swelling behavior of volcanic rocks under cyclic wetting and drying," International Journal of Rock Mechanics and Mining Sciences, vol. 80, pp. 231-240, 2015.

[10] R. Doostmohammadi, M. Moosavi, T. Mutschler, and C. Osan, "Influence of cyclic wetting and drying on swelling behavior of mudstone in south west of Iran," Environmental Geology, vol. 58, no. 5, pp. 999-1009, 2009.

[11] S. M. Rao, B. V. V. Reddy, and M. Muttharam, "The impact of cyclic wetting and drying on the swelling behaviour of stabilized expansive soils," Engineering Geology, vol. 60, no. 1-4, pp. 223-233, 2001.

[12] X. Liu, L. Zhang, and Y. Fu, "Experimental study of mechanical properties of argillaceous sandstone under wet and dry cycle in acid environment," Rock and Soil Mechanics, vol. 35, no. 2, pp. 45-52, 2014.

[13] X. Liu, L. Zhang, Y. Fu, and Z. Wang, "Mechanical properties of argillaceous sandstone under wet and dry cycle in acid environment," Electronic Journal of Geotechnical Engineering, vol. 19, pp. 1433-1446, 2014.

[14] L. Zhang, Study on Macro-Meso Damage Characteristics of Argillaceous Sandstone under Dry-Wet Cycle in Acidic Condition, Chongqing University, Chongqing, China, 2014.

[15] Z. Zhao, J. Yang, D. Zhang, and H. Peng, "Effects of wetting and cyclic wetting-drying on tensile strength of sandstone with a low clay mineral content," Rock Mechanics and Rock Engineering, vol. 50, no. 2, pp. 485-491, 2016. 
[16] T. Liu and P. Cao, "Testing study of subcritical crack growth mechanism during water rock interaction," Geotechnical and Geological Engineering, vol. 34, no. 4, pp. 923-929, 2016.

[17] F. Saleh-Mbemba, M. Aubertin, M. Mbonimpa, and L. Li, "Experimental characterization of the shrinkage and water retention behaviour of tailings from hard rock mines," Geotechnical and Geological Engineering, vol. 34, no. 1, pp. 251-266, 2015.

[18] H. L. Wang, W. Y. Xu, and J. F. Shao, "Experimental researches on hydro-mechanical properties of altered rock under confining pressures," Rock Mechanics and Rock Engineering, vol. 47, no. 2, pp. 485-493, 2014.

[19] M. Kohno and H. Maeda, "Relationship between point load strength index and uniaxial compressive strength of hydrothermally altered soft rocks," International Journal of Rock Mechanics and Mining Sciences, vol. 50, no. 1, pp. 147-157, 2012

[20] X. Chen, H. Fu, Z. Qin, and X. Liu, "Effects of hydrochemical effects and wet-drying cycles on mechanical properties of alluvial rocks," Mining Research and Development, vol. 37, no. 1, pp. 98-102, 2017. 


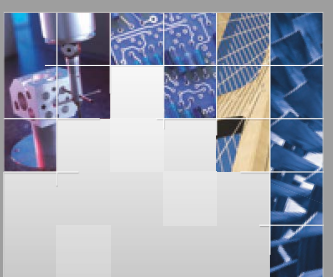

\section{Enfincering}
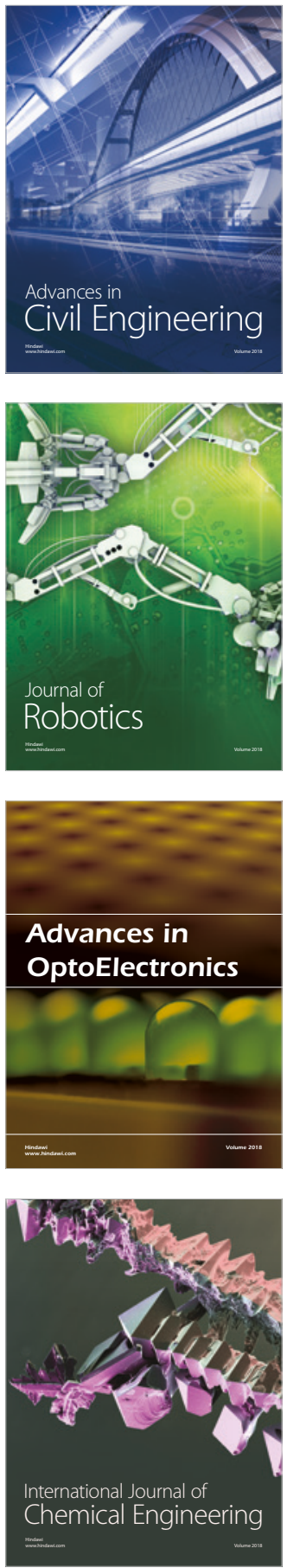

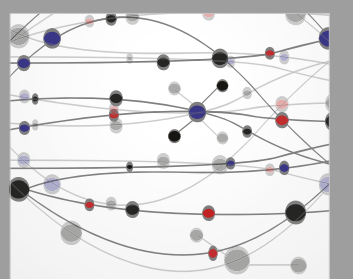

\section{Rotating \\ Machinery}

The Scientific World Journal

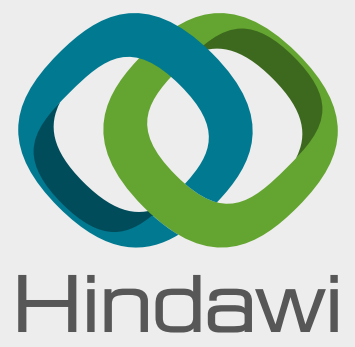

Submit your manuscripts at

www.hindawi.com
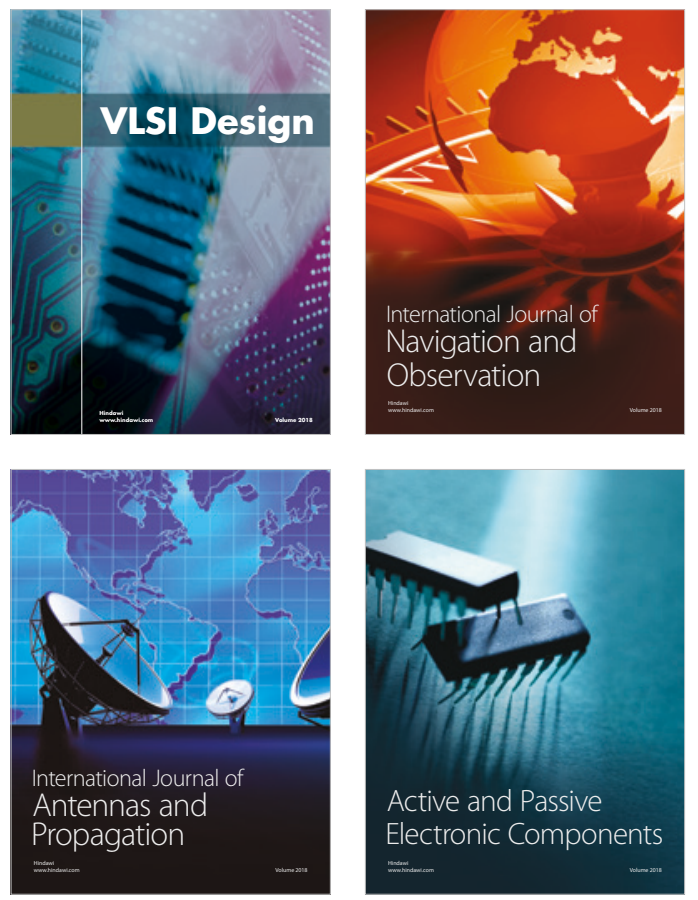
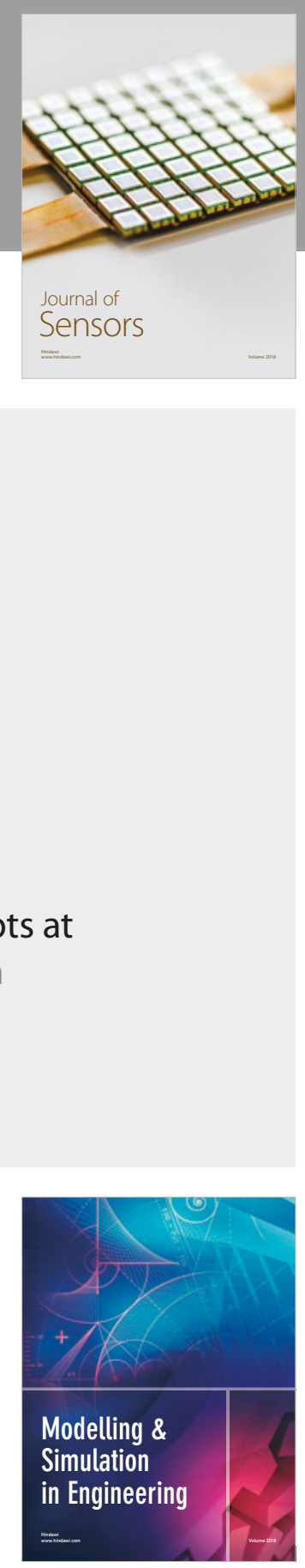

\section{Advances \\ Multimedia}
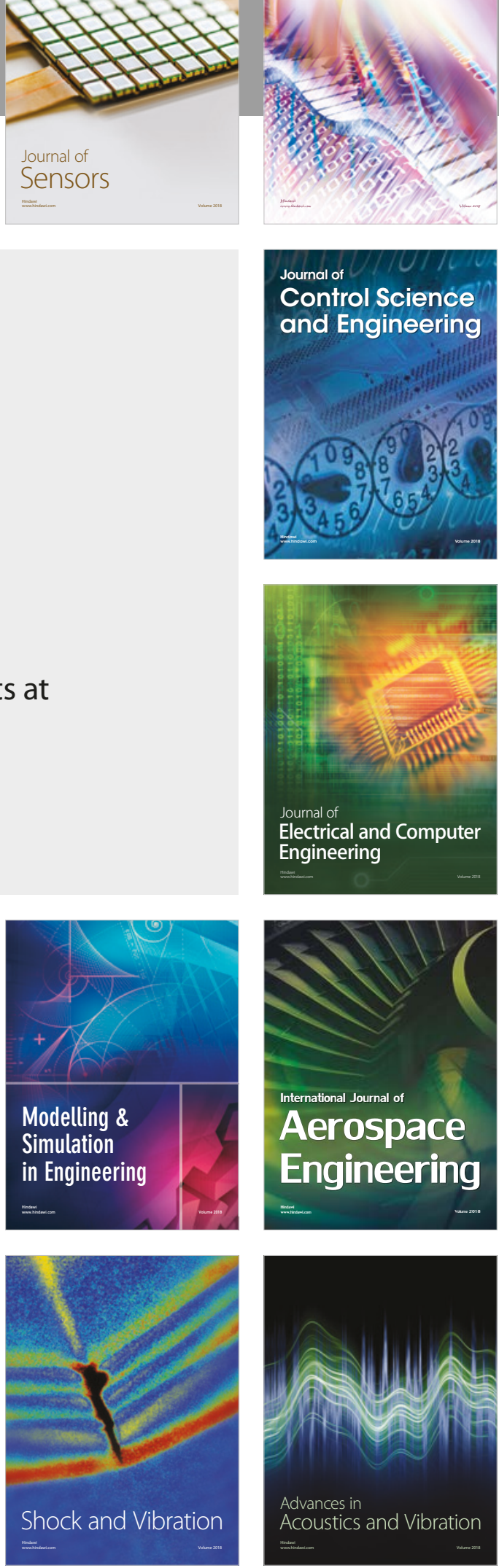